\title{
Community, joy, and the intimacy of narrative in Beowulf
}

\author{
Benjamin A. Saltzman
}

1a. to make internal

1b. to make (person) intimate with (another)

2. to make known, intimate, explain, or communicate

Dictionary of Medieval Latin from British Sources, s.v. intimare ${ }^{1}$

All great storytellers have in common the freedom with which they move up and down the rungs of their experiences as on a ladder. A ladder extending downward to the interior of the earth and disappearing into the clouds is the image for a collective experience to which even the deepest shock of every individual experience, death, constitutes no impediment or barrier.

Walter Benjamin ${ }^{2}$

Intimacy is etymologically bound to the medieval Latin word intimare, which denotes primarily a movement inwards, but also a mode of verbal communication, of making known, of announcing, of explanation. Today, these two senses are divided between, for instance, the adjective ('intimate') and the verb ('to intimate'), and when juxtaposed they seem to represent two radically antithetical phenomena. The one tends to imply internalized private reticence; the other, externalized public expression. But in Beowulf, these two senses of intimacy powerfully converge at moments when stories are shared and recited: moments in which knowledge is communicated through narrative and community is inwardly synthesized. It is in these moments of convergence between narrative and communal intimacy that a profound experience of joy tends to materialize in the poem.

The first such communal experience of joy is short-lived, destroyed almost as quickly as it is created. Set in motion by the construction of Heorot, the hall Grendel would eventually attack, that 'healærna mæst' (greatest of hall buildings) (78a), a space for community quickly opens up within its walls: 'ond pær on innan eall gedælan / geongum ond ealdum swylc him God sealde' (and 
there within, he shared everything with young and old, that which God had given) (71-2). ${ }^{3}$ Within Heorot, the community is supplied and fortified by the all-encompassing gifts of God, which are shared internally ('on innan') with all those in the hall. Let us consider this communal experience to be one important form of intimacy: we might call it communal intimacy. Reflecting the first etymological sense described above, such communal intimacy constitutes internal coherence. Yet while such coherence seems to exist in spite of differences ('geongum ond ealdum' might imply one form of diversity, though it passes over, say, status and gender), it is often created in opposition to external forces, as we will see in a moment. This and subsequent images of community in Beowulf (as well as in many other Old English poems) reflect an important feature of the poem's hall culture, which, as Hugh Magennis has shown with great nuance, comes to epitomize literary conceptions of community especially as it is formed around gift giving and events of feasting and drinking. ${ }^{4}$ Yet in Nicole Guenther Discenza's analysis, these desirable features of the hall - safety, joy, and art - are often in conflict with the hall's vulnerability to 'threats from outsiders, threats from within, and threats from time'.

Emerging alongside the communal intimacy of the hall, narrative intimacy reflects the second etymological sense described above, as it entails the creation and sharing of knowledge and stories. ${ }^{6}$ The naming of Heorot is a perfect example: 'scop him Heort naman / se pe his wordes geweald wide hæfde' (he assigned it the name 'Heorot', he who wields widely the power of his speech) (78b-79). The process of naming is a process of creation that takes place alongside the construction of the hall itself. The first word of this clause and its main verb ('scop', preterit of scyppan, here with the sense of 'to assign', but ordinarily with the sense of 'to create') evokes simultaneously the creative power of God (Scyppend) and of the poet $(s c o p)$. Even as these lines emphasize the power of words, then, they remain ambiguous about who actually assigns the name to the hall: it could certainly be Hrothgar (as the context seems to suggest and scholars tend to infer), but it could also be scop or even God, given the emphasis on the power of words and the action suggested by the verb scyppan. Over the course of the poem, different characters - Heorot's scop, Hrothgar, Unferth, and even Beowulf himself - take up the creative power of words by narrating various stories, stories that may feel like digressions, but in fact constitute (as scholars now tend to believe) an integral 
part of the poem. ${ }^{7}$ These instances of storytelling tend to coincide with moments of communal joy.

The naming of the hall thus gives way to a joyful scene, filtered through the external perspective of Grendel, the poem's first monster, as he listens from outside to the delightful sound loudly emanating from inside Heorot ('dream gehyrde / hludne in healle') (88b-89a). That sound of joy is a combination of music and storytelling: 'Pær wæs hearpan sweg, / swutol sang scopes. Sægde se be cupe / frumsceaft fira feorran reccan, / cwæð pæt se ælmihtiga eorðan worhte' ('There was the sound of the harp, the clear song of the scop. He spoke, he who knew how to narrate the creation of humankind from long ago, said that the almighty created the world) (89b-92). To celebrate the construction of this communal space, the scop (perhaps the same one who gives Heorot its name) fittingly recites the story of the creation of the world and humanity, appearing to follow the first book of Genesis. This recitation mirrors the communal intimacy of the hall through a process of narrative intimation, in which the sharing of knowledge ('se pe cupe ... reccan') ${ }^{8}$ creates communal familiarity around the story itself. ${ }^{9}$ The creative power of words thus moves from the naming of the hall ('scop him Heort naman') (78b) to the scop's narrative of creation ('swutol sang scopes') (90a) to God's creation of life itself ('life ac gesceop') (97b). All three points of narrative intimation reinforce communal intimacy.

This celebratory scene of poetic recitation concludes with the reiterated joy experienced by the community within the hall, which is quickly interrupted by Grendel's re-emergence in the poem: 'Swa ða drihtguman dreamum lifdon / eadiglice, oð ðæt an ongan / fyrene fremman feond on helle' (So these retainers lived in joy, blessedly, until one began to commit his crimes, a fiend from hell) (99-101). The reader might have even temporarily forgotten that the song of the scop and Heorot's joyous sounds have been heard by Grendel all along ('dream gehyrde') (88b). Indeed, the Beowulf poet sets those joys in stark relief against Grendel's marginalized perspective and dejected state of exile, even as we might imagine Grendel sharing with his mother and the other monstrous kin of Cain a different kind of intimacy unregistered by the poet. The communal and narrative intimacy within the hall is thus formed in relation to Grendel's exile, while his story is introduced into the hall through the narrative trajectory of the scop's tale of creation. Although left unstated, that tale implicitly anticipates the story of Cain and Abel, 
who as the children of Adam and Eve appear in Genesis shortly after the creation.

So as one spectre of Cain is anticipated by the scop's narrative, another bursts in through the door:

sibðan him scyppen forscrifen hæfde

in Caines cynne - pone cwealm gewræc

ece drihten, pæs be he Abel slog;

ne gefeah he pære fæhðe, ac he hine feor forwræc,

metod for by mane mancynne fram. (106-10)

(since the Creator had condemned him among the kin of Cain - the eternal Lord avenged that murder, in which he slew Abel; he took no joy in that feud, but for that crime the Maker expelled him far from mankind.)

Grendel's identity as an outsider, his alienated perspective, and his disruptive intrusion into the joyful hall are explained as a consequence of Cain's fratricide, which is already subtly intimated through the scop's account of Genesis; or, if not through the scop's account, then through the Beowulf poet's implicit continuation of that account in the description of Grendel's lineage. ${ }^{10}$ One way, therefore, to think about narrative intimacy as it operates here is that it creates or reinforces a community around a shared body of knowledge, but it also has the potential to disrupt that community as it introduces knowledge from the outside.

If taken further, this point raises an important question: Is intimacy always dependent upon some form of exclusion? Intimacy's etymological opposition to the external certainly suggests so. Moreover, when intimacy informs the nature of community, as community is often constructed and conceived around an enclosing or unifying identity within which intimacy becomes the operative feature, community and its relation to exteriority become more complicated. The dissymmetry of the Other's perspective in relation to a community's homogeneity, for example, has provoked Maurice Blanchot to examine 'whether the community ... does not in the end always posit the absence of community'. ${ }^{11}$ For readers of Beowulf, where Grendel's identity and actions are posited in relation to the community at Heorot, or for readers of, say, The Wanderer, which imagines community from the perspective of one who has lost it, Blanchot's logic might be especially compelling.

But community also perhaps relies on an even more fundamental externality. 'What is common', as Jean-Luc Nancy puts it, 'is the 
sharing of finitude', the fact that as humans we all will face death at some point; for Nancy, this finitude functions in the context of community as a 'being-outside, an "outside" prior to all "inside". 12 One way to approach the question, then, is through this negative account, in which 'community is made or is formed by the retreat or by the subtraction' of the subject. ${ }^{13}$ In other words, community always requires the subject to experience its own externalized existence and singular finitude. Roberto Esposito offers a more radical approach: community is not a form of communal ownership or possession of some central trait, object, or similarity, not 'a corporation in which the individuals are founded in a larger individual', but rather a voiding of subjectivity itself, as the subjects enter into a 'common non-belonging', a giving over of the subject to the communal: 'In the community, subjects do not find a principle of identification nor an aseptic enclosure within which they can establish transparent communication ... They don't find anything else except that void, that distance, that extraneousness that constitutes them as being missing from themselves. ${ }^{14}$ In these formulations of community, we encounter fundamental exclusion even at the level of the individual subject.

As the formation of community can rely on mechanisms of exteriority and, at times, exclusion, I'm reminded of work by Lauren Berlant, who has shown how narratives of intimacy have a way of privileging one form of life at the expense of numerous others:

Those who don't or can't find their way in that story - the queers, the single, the something else - can become so easily unimaginable, even often to themselves. Yet it is hard not to see lying about everywhere the detritus and the amputations that come from attempts to fit into the fold ... To rethink intimacy is to appraise how we have been and how we live and how we might imagine lives that make more sense than the ones so many are living. ${ }^{15}$

Community and narratives of intimacy can powerfully shape life, indeed the individual lives and livability of those who experience intimacy from within and those who experience it as abjection from without. In Beowulf, then, the work of the scop seems to reinforce communal bonds in opposition to the world outside; and yet the scop also provides a way around that binary, as the stories he tells can be used to imagine the perspective of others and incorporate them into the otherwise closed communal space. Narrative intimacy, in other words, always also has the potential to traverse the boundaries established by those exclusive and cohesive 
forces that typically animate the poem's vision of communal intimacy.

These boundaries are tested not only by Grendel's violent intrusions, but also with the arrival of Beowulf. ${ }^{16}$ At first, Beowulf is received as a foreigner on the Danish sea-cliffs: though the coastwarden acknowledges that no troop has ever come more openly ('cuðlicor') (244a) and that he has never seen a greater warrior on earth ('Næfre ic maran geseah / eorla ofer eorpan') (247b-248a), the warden nevertheless demands to know their lineage ('frumcyn witan') (252a) in order to ensure they are not spies ('leassceaweras') (253a). Satisfied with Beowulf's response, the coast-warden leads the Geatish troop to Heorot, where Wulfgar welcomes them and announces their arrival to Hrothgar, who in turn commands that they be invited to see the assembly of kinsmen gathered together in the hall ('seon sibbegedriht samod ætgædere') (387). Speaking from within the hall, Wulfgar then summons Beowulf inside ('word inne abead') (390b). These scenes repeatedly emphasize the coherent gathering and unity (we might say, 'intimacy') of the Danes, reinforced at each of the several stages in which Beowulf and his troop are granted, with some scepticism, entrance into this intimate community and finally into Heorot itself. ${ }^{17}$ After Beowulf enters and exchanges words with Hrothgar about Grendel's terror (the external threat), he and his troop are invited to sit on a bench inside the hall. These welcoming and inclusive gestures through which the Geats are embraced by the community at Heorot ('geador ætsomne') (491b) culminate in the appearance once again of a scop: 'Scop hwilum sang / hador on Heorote' (the clear-voiced scop sang for a while) (496b-497a). And as with the scop's song of creation in celebrating the construction of Heorot, once again communal joy ensues: 'Pær wæs hæleða dream, / duguð unlytel Dena ond Wedera' ('There was the joy of heroes, a great gathering of Danes and Geats) (497b-498). Scop and dream are very much allied, as the two groups of retainers come together through this joyful experience of not only drink and feast, but also song, music, and the recitation of stories.

But this communal joy and the song of the scop are once again promptly disrupted, as Unferth unbinds his battle-rune ('onband beadurune') (501a) and launches an invective at Beowulf, calling into question his strength and courage by recounting a failed swimming contest from his youth. The figure of Unferth has vexed scholars almost as much as he himself seems vexed by Beowulf's bravery. James L. Rosier's 1962 article on the subject bolstered the 
predominantly negative readings of Unferth by demonstrating that the character's epithet ('Unferp pyle') (1165b) did not merely denote a general kind of spokesman, orator, or official entertainer, but also carried a pejorative sense evocative of a more wicked role. ${ }^{18}$ This linguistic argument has been disputed, but the underlying view of Unferth as a troubling character has been hard to shake, even in arguments that defend his vital function both in Heorot and in the narrative of the poem. ${ }^{19}$ As Rosier puts it, though, this scene enacts a 'dramatic oscillation of joy and strife' between, for instance, the scop's joyful song and Unferth's treacherous incursion - an internal oscillation similar to that introduced by Grendel (an 'external threat'), for 'both are associated with Cain, the one by the deed of fratricide, the other in lineage; both are consigned to hell; and both disrupt the joy of the hall, Unferth by his battle-rune, and Grendel by physical assault'. ${ }^{20}$ This particular reading of Unferth seems right, even in light of the completely divergent view, taken by Norman E. Eliason a year later, that Unferth (the pyle) might in fact be the very same scop who elsewhere sings such clear songs of joy. ${ }^{21}$ This possibility is intriguing, for it suggests that the dramatic oscillation between joy and strife is actually a congruous feature of the Danish community itself, as potentially a single character utilizes narrative both to delight and to antagonize, both to cement community and to alienate an outsider.

Taken together, the two views advanced by Rosier and Eliason - in which Unferth's invective sharply turns joy into strife and in which this shift exemplifies a kind of communal intimacy at Heorot through storytelling - appeal to Edward B. Irving's reading of Unferth as a 'spokesman for the community of Danes', as he speaks 'for their anger, their pride, their frustrations, their xenophobia, and their honestly grateful generosity of spirit'. ${ }^{22}$ Irving's observation is powerful not merely for its crisp realization of Unferth's purpose, but also for its recognition of the way in which community can be formed around 'negative and hidden dimensions', even dimensions that conflict with one another, even dimensions that rely on xenophobia and alienation. The dialectic of narrative and its digressive interruptions - whether recited by scop or pyle - has the unique power to move between these dimensions of intimacy; to alienate, yet to express the deep, sometimes divergent sentiments and epistemologies of a community. Irving's reading would make Unferth not so much an expression of treachery (an internal threat to the community) as, on the contrary, an assertion of that very community. 
What is at stake in the Unferth episode is not only the assertion of a Danish community, but also the positioning of Beowulf within that community at a time when it is being repeatedly threatened from the outside by that unknown monster Grendel ('deogol dædhata') (275a). ${ }^{23}$ The process of narrative recitation in the Unferth episode, even if it is clearly aggressive, is necessarily an epistemological process of vetting the figure of Beowulf - discerning him from known quantities - as he sits welcomed with wine in the midst of the hall. Unferth's sentiment is clearly aggressive, yet it is crucial that this sentiment should be manifested in the form of narrative (by telling the story of a swimming contest) as opposed to an unmediated assault (whether verbal or physical). Narrative is critical here because it allows for the possibility of inclusion by intimating Beowulf into the community, just as Grendel - perhaps not with the best outcome - is subtly intimated via Cain into the scop's earlier narrative of creation.

The effect of narrative intimacy can be seen, for example, in the way Unferth does not outright attack Beowulf by condemning his pride or disputing his courage, but begins instead with a question: 'Eart bu se Beowulf, se pe ... ?' (Are you the Beowulf, who ... ?) (506a). Though followed by accusations of pride ('wlence') (508a) and foolish boasting ('dolgilpe') (509a), Unferth's opening question allows Beowulf any number of different responses. He could have easily dismissed the attack ('you're drunk, Unferth, and you've clearly got the wrong guy!'), but instead Beowulf opts to present a counter-narrative: 'soð ic talige' (I shall tell the truth) (532b). Beowulf's competing account of the swimming match and his promise to defeat Grendel allows him to position himself in opposition to a more threatening outsider and thereby intimate himself into the community. That process of intimation was opened up by Unferth's narrativistic invective, giving Beowulf the opportunity to tell a narrative that not only interjects his experience into the community, but also realigns the community in opposition to the more pressing danger posed by Grendel.

This process of narrative intimation is immediately followed by further scenes of joy: 'Đær wæs hælepa hleahtor, hlyn swynsode, / word wæron wynsume' (There was laughter of men, making pleasant sound, the words were joyous) (611-12b). The joy in Heorot at this moment surely reflects the hopeful anticipation of Grendel's impending defeat, but it is also attached, once again, to the power of words. Accordingly, the Unferth episode is followed by Wealhðeow's gracious passing of the cup, which is followed by Beowulf's reiterated 
pledge of courage, at which point the scene returns, as before, to one of joyful intimacy formed around spoken words: 'Pa wæs eft swa ær inne on healle / pryðword sprecen, ðeod on sælum, / sigefolca sweg' ('Then, afterwards as before, noble words were spoken inside that hall, the people joyful, the sounds of a victorious people) (642-4a). Restored is the joy originally celebrated in Heorot, a joy simultaneously tied both to the people inside the hall ('inne on healle') and the sounds emanating from it - a joy tied to powerful, strong, noble words ('pryðword'), which though unspecified seem to evoke the words of the scop who spoke of creation and who may have assigned Heorot its name.

To be sure, these moments of joy often accompany the anticipation or celebration of victory. As the troop returns from the mere (where Grendel has retreated, wounded and presumed dead), Beowulf's initial triumph is celebrated along a joyful journey ('gomenwape') (854b) with the recitation of tales:

Hwilum cyninges begn,

guma gilphlæden, gidda gemyndig,

se ðe eal fela ealdgesegena

worn gemunde, word oper fand

soðe gebunden; secg eft ongan

sið Beowulfes snyttrum styrian

ond on sped wrecan spel gerade, wordum wrixlan. $(867 \mathrm{~b}-874 \mathrm{a})$

(Meanwhile, the king's thegn, filled with tales of men, mindful of songs, he who remembered so many of the ancient legends, composed different words truly bound; the man began to recite again the exploits of Beowulf, to stir up with wisdom and to rouse with skill an apt story, to weave with words.)

Even before returning to Heorot, Beowulf's victory is already being woven into the very narrative fabric that defines the communal intimacy of the Danes. ${ }^{24}$ The binding and weaving of words - both in the poetic process described by these lines and the stylistic weaving of sounds in the lines themselves, as Megan Cavell has shown reflects the interlacing that is such a fundamental feature of much Old English poetic composition. ${ }^{25}$ The alliterative envelope pattern in lines $870-4(w-s-s-s-w),{ }^{26}$ for example, produces a kind of poetic or sonic intimacy in which words and sounds internally envelop themselves, indeed are truly bound, if that is what 'soðe gebunden' is supposed to mean. Of course, envelope patterns and alliteration are common features of Old English poetry, though not 
always consistently applied in the same way, nor always sonically intimate as here, nor always the product of communally determined poetic principles. ${ }^{27}$ But here, these formal techniques suggest the inclusion of Beowulf in the community of Danes as his name falls in the very centre of this alliterative envelope. This poetic process is then replicated in the narrative itself, as Beowulf's defeat of Grendel in the present is woven into the legendary narrative of Sigemund from the past, and likewise Sigemund's defeat of the dragon weaves in the anticipation of Beowulf's own dragon fight at the end of the poem. ${ }^{28}$

At moments like these, the repeated appearance of storytellers gives the poem a kind of rhythm that has often been noted. Scholars still refer to these stories as digressions, a slightly pejorative designation that implies separation, even though most readers follow Adrien Bonjour in accepting them as an integral feature of the poem's aesthetic. ${ }^{29}$ In these digressions, the scop also shapes the idea of the communal by weaving the community's experiences into a longer narrative history. We see this process not only in the juxtaposition of Beowulf and Sigemund, but also in the celebration at Heorot following Grendel's defeat, a victory once again culminating in internal cohesion: 'Heorot innan wæs / freondum afylled' (inside, Heorot was filled with friends) $(1017 \mathrm{~b}-1018 \mathrm{a}) .{ }^{30}$ And this internal cohesion is reinforced both through gift giving and, once again, through the recital of stories, this time the Finn episode: ${ }^{31}$

\author{
Pær wæs sang ond sweg samod ætgædere \\ fore Healfdenes hildewisan, \\ gomenwudu greted, gid oft wrecen, \\ ðonne healgamen Hropgares scop \\ æfter medobence mænan scolde \\ be Finnes eaferan. (1063-8a)
}

(There was song and music assembled together in the presence of Healfdene's battle-leader, the joyous-wood was played, tales often narrated, when Hrothgar's scop would perform hall-joy among the mead-benches, tell about the sons of Finn.) $)^{32}$

Elsewhere in the poem, the formulaic phrase 'samod ætgædere' tends to refer to an assembly of men $(387 \mathrm{~b}, 729 \mathrm{~b})$ or their war-gear (329b), but here the formula seems to refer either to the mingling of song and music or to a gathering of listeners enjoying those sounds of the harp. In other words, the phrase poetically joins together song and community. As we have seen, where song and community meet there is often joy, and here the joyful sound of the harp is conveyed in a kenning, 'gomenwudu', ${ }^{33}$ that speaks not only to the 
instrument itself, but also to the joyful environment in which it is found: the amusement and joy of the hall itself ('healgamen'). Both the harp ('gomenwudu') and the recitation ('healgamen') produce and represent a communal joy that takes place around acts of storytelling, song, and poetry. Just as joyful sounds of community introduce the story of Finn, its end is likewise met with more communal sounds of joy: 'Leoð wæs asungen, / gleomannes gyd. Gamen eft astah, / beorhtode bencsweg; byrelas sealdon / win of wunderfatum' (The song was sung, the entertainer's tale, joyous sounds arose again, the sounds from the bench glittered, the cup-bearers gave wine from wondrous vessels) (1159b-1162a). We can see how these expressions of communal joy - wine and song, for instance - intersect with one another as they surround the act of storytelling itself; narrative intimacy is enclosed by communal intimacy.

When these events are retold by Beowulf upon his return home to Hygelac, they again demonstrate this integral connection between communal joy and storytelling, as that communal experience now becomes a new source of narrative intimacy. Beowulf's words, in other words, reiterate the poet's earlier emphasis on the affiliation between communal intimacy and narrative intimacy:

ond we to symble geseten hæfdon.

Par waes gidd ond gleo; gomela Scilding,

felafricgende, feorran rehte;

hwilum hildedeor hearpan wynne, gomenwudu grette, hwilum gyd awræc

soð ond sarlic, hwilum syllic spell

rehte æfter rihte rumheort cyning;

hwilum eft ongan, eldo gebunden, gomel guðwiga gioguðe cwiðan, hildestrengo; hreðer inne weoll, ponne he wintrum frod worn gemunde.

Swa we pær inne andlangne dæg niode naman, oð ðæt niht becwom oðer to yldum. (2104-17a, italics added for emphasis)

(And we gathered at the feast. There was song and joy; the aged Scylding, well-informed, told of distant times; at times, the brave warrior played the harp with delight, touched the joyous-wood; at times, he narrated a tale, both true and sad; at times, the generoushearted king recited a wondrous story; at times, that aged warrior, bound by old-age, told of his youth again, his battle strength; his heart welled up within him, as he, wise in winters, remembered so much. So, there inside we took our ease all day long, until another night came upon men.) 
In addition to providing a more detailed account of the storytelling at Heorot following Grendel's defeat, Beowulf weaves in language from the poet's earlier description of these events. Some words and phrases are almost identical: 'worn gemunde' is used twice (870a and 2114b), and 'gomenwudu grette' (2108a) echoes 'gomenwudu greted' (1065a). Others are in parallel: 'Pær wæs gidd ond gleo' (2105a) mirrors 'Pær wæs sang ond sweg' (1063a). A few are translated into a different context: 'eldo gebunden' describes Hrothgar's age (2111b), while 'soðe gebunden' describes the binding of truth (871a). And still others correspond on a formal level: the repetition of 'hwilum' (2107a, 2108b, 2109b, 2111a) recalls a similar pattern introducing the story of Sigemund (864a, 867b, 916a). The stuff of metapoetic description, in other words, gets incorporated into Beowulf's narrative and thus the narrative of the poem itself.

This process mirrors the way in which the storyteller, in this case Hrothgar, reaches inside his own memories to produce a story that in turn incorporates the communal intimacy of the audience. The internalized welling of Hrothgar's heart ('hreðer inne weoll') (2113b), which tumultuously represents almost an eternity ('wintrum frod'), transpires into the 'we' that inhabits the interior of the hall ('we pær inne') for a finite duration of time ('andlangne dæg') that must nevertheless come to an end as night returns ('niht becwom').

Walter Benjamin was on to something. His essay lamenting the disappearance of the storyteller - who he sees as a medieval figure sacrificed to modernity's fondness for and capitalism's commodification of the novel - speaks to the way in which storytelling integrates the listener into the experience of the teller. It is, for Benjamin, an essentially communal exercise: 'The storyteller takes what he tells from experience - his own or that reported by others. And he in turn makes it the experience of those who are listening to his tale. ${ }^{34}$ The novelist, by contrast, 'has isolated himself' and so too has his reader, 'more so than any other reader', for in his solitude, 'the reader of a novel seizes upon his material more jealously than anyone else. He is ready to make it completely his own, to devour it, as it were. ${ }^{35}$ While Benjamin seems perhaps nostalgic for the vague traditions of ancient storytellers, by contrasting the alienation that accompanies the commodified novel with what existed before, with a historical phenomenon that seems also to have characterized the kind of experience that takes place around the scop in Beowulf, he holds up the scop as a measure of what the novel, always-already commodified, cannot do. ${ }^{36} \mathrm{It}$ is an event in which a storyteller such as Hrothgar or Unferth or Beowulf takes up some experience - his 
own or that garnered from others - and turns it into a communal experience of intimacy through narrative. ${ }^{37}$

For Benjamin, the storyteller thus has a pre-commodity function that offers us a post-commodity, communist horizon. This decommodified narrative experience is Benjamin's ladder, on which the storyteller freely ascends 'into the clouds' and descends 'to the interior of the earth' ${ }^{38}$ It is a perplexing image, and it is not especially clear how it is meant to represent what Benjamin deems 'a collective experience'. But the storyteller's movements on the ladder somehow allow him the liberty of descending into the depths of his own memory and rendering it collective, inviting the listener to participate by in turn attempting to remember the story and integrate it into his own experience. In this way, storytelling resists the effects of death, the finitude of human life, the basis of community. ${ }^{39}$ As the 'deepest shock of every individual experience', death 'constitutes no impediment or barrier' to the storyteller's free movement on the ladder of narrative; where for modernity 'the thought of death has declined in omnipresence and vividness', it is for Benjamin 'the sanction of everything that the storyteller can tell. He has borrowed his authority from death. ${ }^{40}$ This authority is vested in him not only because the stories he tells often grapple with the reality of death, but also because the process of storytelling invites listeners to remember, perpetuate, and pass along their own experience of the story, which in turn becomes a part of their own experience qua experience and thus the source for future expressions of what we are calling narrative intimacy.

Beowulf's return to Hygelac epitomizes this process, for not only does Beowulf integrate the celebratory storytelling of Heorot (and the language used to describe it) into his own narrative experience of events, but in doing so he also repeatedly emphasizes Hrothgar's old age ('gomela Scilding', 'eldo gebunden', 'gomel guðwiga') as he shares stories drawn from his youthful memories, bringing those stories through the temporality of the present into the immortal atemporality of narrative intimacy and the communal experience that forms around it. The stories endure, moreover, even when night descends and brings death to individuals in the hall (in this case, one particular individual, Eschere, has died at the hands of Grendel's mother); the stories endure, in other words, because both Beowulf and the Beowulf poet remember and retell them.

In retrospect, despite the communal joy that all of these moments of intimacy represent, they are frequently interrupted by death and killing. But although these interruptions disrupt the community, 
they do not constitute, as Benjamin puts it, an 'impediment or barrier' to the narrative intimacy produced by the poem's storytellers. The arrival of Grendel's mother under cover of darkness while the community sleeps and her snatching of Eschere, for instance, interrupts the earlier joyful harp and song, but the particular instance of death only gets integrated back into the narrative that Beowulf tells to Hygelac and that the Beowulf poet tells to his readers. This process of narrative intimation is precisely how the communal experience is formed in the face of human finitude and the 'deepest shock of every individual experience'. ${ }^{41}$

That is not to say that those shocks do not matter, but rather that narrative intimacy has a way of incorporating them. In fact, such rhythmic shocks of death punctuate the poem's vision of communal intimacy in a way that seems to counterbalance the joy that such intimacy celebrates in the daylight only to be destroyed as soon as the sun sets. By the end of the poem, as Beowulf prepares for his final fight against the dragon and the setting of his own life ('wælfus' [ready to be slain] (2420a)), he reflects on the narrative of his own lineage, beginning with his adoption by Hrethel as a child. The story quickly shifts to explain Hrethel's grief over the accidental death of his eldest son by the tip of his brother's arrow, imagined from the perspective of a criminal's father:

\footnotetext{
Swa bið geomorlic gomelum ceorle

to gebidanne, pæt his byre ride

giong on galgan. Ponne he gyd wrece,

sarigne sang, bonne his sunu hangað

hrefne to hroðre, ond he him helpe ne mæg,

eald ond infrod ænige gefremman. (2444-9)
}

(So it is mournful for an old man to see his own son swing, young on the gallows. He shall recount a tale, a sorrowful song, when his son hangs - a comfort to ravens - and, though old and wise, he cannot provide him any help.)

Up to this point, the poem has repeatedly stressed the connection between joy and songs. But sometimes, songs and stories are unavoidably sad. By Beowulf's account, for instance, Hrothgar 'gyd awræc / soð ond sarlic' (narrated a tale, both true and sad) (2108b-2109a). Now, as Beowulf recounts how the aged Hrethel helplessly confronted his young son's execution, he acknowledges that Hrethel has no choice but to commemorate it in song with a sorrowful tale. There is no joy to be had in this scene of death, other than by the raven 
- a comparison that sets the scene off from the more common images of joyful storytelling. This lack of joy is only compounded by the consequent desolation of the son's hall and the community it housed:

Gesyhð sorhcearig on his suna bure
winsele westne, windge reste
reotge berofene; ridend swefað,
hæleð in hoðman; nis bær hearpan sweg,
gomen in geardum, swylce ðær iu wæron. (2455-9)

(He looks sorrowfully on his son's dwelling, the wine-hall empty, the windswept home deprived of joy - the riders sleep, heroes in darkness; there is no sound of the harp, joy in the court, as there was before.)

What makes this son's death all the more devastating is the obliteration of the very symbols of communal joy: the heroes now sleeping in darkness, the sound of the harp now divorced from its usual joy, the word 'gomen' (2459a) even extracted from the kenning gomen$w u d u$, and set aside in a separate line and in the past ('swylce ðær iu wæron') (2459b).

In a union typically symbolized by the hall, joy and community clearly go hand in hand. To be disconnected from such a hall, as poems such as The Wanderer so enthrallingly convey, is thus to experience a profoundly mournful state of isolation. But we are also frequently reminded that the physical walls of a hall can fall into ruin and its community can fall away, both easily interrupted by natural forces and death. ${ }^{42}$ As Patricia Dailey has shown, however, poetry has a way of preserving a remnant of the subject that extends beyond the gravitational pull of the past and the erosion of the physical world in the present. ${ }^{43}$ Songs and stories might seem inherently transient, for they are far less tangible than a wooden hall or stone buildings or a hoard of treasure, yet they have an eerily joyful way of resisting death - that shock of the individual - in their potential to form a more durable community of listeners and readers.

Indeed, Old English poets seem to have recognized this power of narrative, as the poem Maxims I makes quite evident: 'Longað ponne by læs pe him con leopa worn, / oppe mid hondum con hearpan gretan; / hafap him his gliwes giefe, pe him god sealde ${ }^{44}$ (He longs less, who knows many tales or knows how to greet the harp with his hands; he has within himself the gift of music/joy, which God gave him). The knowledge of poems, songs, narratives, 
stories - however we choose to translate leop - somehow gives the individual a kind of joy that only elsewhere seems to be found either in heaven (that's for another time) or in the communal celebrations of the hall (as we have seen here). But in this aphorism, there is no hall; the tales and the harp are all that keep the individual from longing and sorrow, as the gliw (glee, joy, merriment, but also music) is enjoyed as a gift from God. ${ }^{45}$ Then again, the hall is not entirely absent either. Often, the aphorisms in Maxims I follow one another in tenuous relation, moving from the turbulence of the ocean, for instance, to the importance of dividing up an inheritance (lines 76-9). But sometimes this apparent randomness is interrupted by a series of aphorisms that flow logically from one to the next. Accordingly, what follows this aphorism in praise of poetry is either entirely incongruous or subtly apt. I am inclined to read it as the latter, as the poetic cure for longing is followed immediately by a reflection on how miserable it is to live alone: 'Earm bið se pe sceal ana lifgan, / wineleas wunian hafap him wyrd geteod' ${ }^{46}$ (Wretched is he who must live alone, fate has driven him to dwell friendless). The solution to this lonely misery, if we continue to read Maxims $I$ in sequence, is to ensure that one has a brother ('betre him wære pæt he bropor ahte') (174a). But then after just a few more aphoristic detours, the poem ends with an account of the feud sprung from Cain's murder of his own brother (189-204). It seems that storytelling, after all, is perhaps the better option for combating solitude and sorrow. If Cain betokens alienation, as the Beowulf poet clearly suggests by drawing Grendel's marginalized lineage back to that act of fratricide, a severance of the most intimate of relationships, then it is instead the storyteller whose narrative intimacy merges into an experience of communal intimacy that can truly transform longing, loneliness, even death.

As a poem, Beowulf achieves this same kind of narrative intimacy from the start: 'Hwæt, we Gar-Dena in geardagum, / peodcyninga prym gefrunon, / hu ða æpelingas ellen fremedon' (Listen, we have heard of the glory of the kings of the Spear-Danes in days gone by, how those princes performed brave deeds) (1-3). These famed opening lines are often remarked upon for the way they incorporate the audience into the narrative of the poem. ${ }^{47}$ Even before the figure of the scop appears in Heorot, even before his songs can animate the community there and alienate Grendel as he listens in from outside, the poet embraces the 'we' who have already heard of past glories, glories from a vague distant past ('in geardagum'), into which the audience is drawn and included: this is the narrative 
intimacy that lays the groundwork for the various experiences of communal joy to come.

To observe the poem's engagement with these experiences of intimacy - where narrative and community intersect - is to invite a reflection upon the ways that our own scholarly narratives and productions of knowledge have the potential to shape the field's commitment to community and inclusivity. It is often through Beowulf that students first encounter Old English as a language and as a field of study. From there, individual experiences differ. When I look back on my early studies, what drove me ultimately to pursue a career in this field was the warmth with which I was initially welcomed into a community of scholars, in particular the New York based Colloquium for Early Medieval Studies (formerly known as the ASSC). I expect others have had similar experiences, but I also know that many have not. It is my impression that the field as a whole and the majority of its individual members tend to welcome with enthusiasm those who share an interest in the culture and literature of early medieval England, yet some who share this interest have experienced a closed field and have not been met with the same kind of friendliness and collegiality that I for one have come to value so greatly. The unevenness of the field's collegiality is certainly changing, and it is my hope that as more students have their interests sparked by Beowulf and other poems, writings, and materials from the period (often through the inspiration of their teachers), they might enter the field under the same or, indeed, better circumstances than I did, warmly and enthusiastically welcomed.

This community and its friendliness ('freondum afylled') (1018a) is one of the things that I think our field, at times and especially in more recent times, does so right. And I am encouraged by the serious efforts that members of our field, both individually and institutionally, have made towards repairing and redressing past exclusionary habits and fostering a more inclusive scholarly environment, embracing the diversity of backgrounds, identities, and areas of academic interest. Yet if Beowulf teaches us anything, it is that the formation of community - no matter how joyous or amiable it might seem - often invites exclusion and hostility towards outsiders, sometimes subtly, sometimes blatantly, and especially in times when resources are made thin or when fears simmer up.

'The field' or 'our field', phrases I have used offhand throughout this chapter, imply collective ownership - with it communal pride and intellectual responsibility, with it the basis for potential exclusivity and alienation. But this focus on collective ownership - what is 
proper - as the underlying function and mechanism of community is deeply problematic, as Esposito's work has taught us. ${ }^{48}$ Even as the very name of the field, until now commonly known as AngloSaxon studies, currently undergoes re-evaluation, these formulations of ownership ('a field', 'the field', but especially 'my field', 'our field') risk alienation: where do the boundaries of the field get drawn? Who gets to choose what work or scholars fall within those boundaries? Can we envision a functional field without such boundaries? ${ }^{49}$ That re-evaluation and self-critique, that ability to create a new narrative without erasing or forgetting its history, is precisely what community can do. As 'this field' has begun to reflect more openly on its own history and is actively working to confront it, to open itself up, to raise awareness, to acknowledge flaws, to become better, I am all the more encouraged in my optimism for its future. ${ }^{50}$

If communal intimacy always has the potential to be exclusionary - the potential, in other words, to process internal cohesion as aggression against others - then Beowulf also seems to suggest that narrative has a powerful capacity to cut across this exclusionary potential. This aspect of the poem speaks, on the one hand, to the field's recent efforts at more conscientious inclusion. ${ }^{51}$ These efforts are inadvertently being shaped by how we read this poem, a poem which in many ways is the force that connects almost every member of this community - regardless of one's department, or nationality, or seniority, or even, say, of one's relative inclination towards philological or theoretical approaches. On the other hand, the poem's depiction of narrative intimacy also speaks to larger issues about the powerful ways in which stories and narratives - domains where truth and fictionality warp and fuse - can create walls around a community to protect it from an imagined enemy and the equally powerful ways that literature and storytelling can alternatively weave in the lived experiences of those on the other side. Communal joy and communal intimacy sound so nice because they imply a happy state of inclusion. But without a radically inclusive form of narrative intimation, intimacy perpetually risks alienation; with it, a truly communal form of joy.

\section{Notes}

1 R. E. Latham and D. R. Howlett, Dictionary of medieval Latin from British sources (London: Oxford University Press, 1975-2013), s.v. intimare; I've slightly modified the form of the entry. Intima in the first sense is often glossed as ingebanc (as a noun) and inweard (as an adjective). 
2 Walter Benjamin, 'The storyteller: reflections on the works of Nikolai Leskov', in Illuminations: essays and reflections, ed. Hannah Arendt (New York: Schocken Books, 1968), pp. 83-109, at 102.

3 All quotations of Beowulf are from R. D. Fulk, Robert E. Bjork, and John D. Niles (eds), Klaeber's Beowulf, 4th edn (Toronto: University of Toronto Press, 2008) and are cited by line number. Translations are my own.

4 Hugh Magennis, Images of community in Old English poetry (Cambridge: Cambridge University Press, 1996), esp. pp. 60-81.

5 Nicole Guenther Discenza, Inhabited spaces: Anglo-Saxon constructions of place ('Toronto: University of Toronto Press, 2017), p. 184.

6 I will occasionally use the term 'narrative intimation' to describe a process that produces 'narrative intimacy'. I have opted for the term 'narrative intimacy' because when the term 'intimacy' is applied to both communal and narrative events alike, we can better reflect upon the continuities between its double-edged etymology and grasp the proximity that these two concepts would have shared in early medieval discourse.

7 On the digressions, see Mary-Kate Hurley's chapter in this volume, pp. 147-63.

8 The connection between intimation and knowledge is reinforced, for instance, in at least one early medieval English glossary, where the word intimandum (to tell, recount, narrate) is glossed as to cydenne (to know); see Jan Hendrik Hessels (ed.), An eighth-century Latin-Anglo-Saxon glossary (Cambridge: Cambridge University Press, 1890; repr. 2011), p. 70 .

9 Brian Stock's notion of a textual community in his The implications of literacy: written language and models of interpretation in the eleventh and twelfth centuries (Princeton, NJ: Princeton University Press, 1983) might be useful to think with here, despite its association with the eleventh and twelfth centuries; see Nicholas Howe, 'The cultural construction of reading in Anglo-Saxon England', in Jonathan Boyarin (ed.), The ethnography of reading (Berkeley, CA: University of California Press, 1993), pp. 58-79. However, the scenes that I am examining in Beowulf depict an oral (as opposed to literate or textual) process of recitation, even as the text of Beowulf itself is a more textual production. On poetic communities in early medieval England, see Emily V. Thornbury, Becoming a poet in Anglo-Saxon England (Cambridge: Cambridge University Press, 2014), pp. 95-160.

10 Jeffrey Jerome Cohen, Of giants (Minneapolis, MN: University of Minnesota Press, 1999), p. 25, for example, argues that Grendel's extimité is realized when he 'intrudes into the narrative just as Hrothgar's scop is singing', timely given the monster's hatred for their music, 'a dynamic metaphor of their communal harmony'. See also Roberto Esposito, Communitas: the origin and destiny of community, trans. Timothy C. Campbell (Stanford, CA: Stanford University Press, 2009), p. 11, on the 
centrality of Cain to the formation of the human community (thinking through Hannah Arendt's interpretation of Augustine).

11 Maurice Blanchot, The unavowable community, trans. Pierre Joris (Barrytown, NY: Station Hill Press, 1988; repr. 2006), p. 3.

12 Jean-Luc Nancy, The disavowed community, trans. Philip Armstrong (New York: Fordham University Press, 2016), p. 9.

13 Jean-Luc Nancy, The inoperative community, trans. Peter Connor et al. (Minneapolis, MN: University of Minnesota Press, 1991), pp. xxxix, 26. Indeed, for Nancy, this finitude enables the very possibility of joy, which 'has meaning and existence, only through community and as its communication' (p. 34).

14 Esposito, Communitas, p. 7.

15 Lauren Berlant, 'Intimacy: a special issue', Critical inquiry, 24.2 (1998), $281-8$, at 286.

16 On the similarities between Beowulf and Grendel (e.g., both are described as 'hall-thegns', 11. 142 and 719), see Andy Orchard, Pride and prodigies: studies in the monsters of the Beowulf-manuscript (Cambridge: D. S. Brewer, 1995), p. 32; Cohen, Of giants, p. 27, notes that Beowulf 'plays the role Grendel previously enacted' in his attack of the mere.

17 For a much more nuanced reading of the numerous scenes of arrival (and departure) in the poem, see John M. Hill, The narrative pulse of Beowulf: arrivals and departures (Toronto: University of Toronto Press, 2008).

18 James L. Rosier, 'Design for treachery: the Unferth intrigue', PMLA, 77.1 (1962), 1-7.

19 Robert E. Bjork, 'Unferth in the hermeneutic circle: a reappraisal of James L. Rosier's "Design for treachery: the Unferth intrigue”, Papers on language and literature, 16 (1980), 133-41. See also R. D. Fulk, 'Unferth and his name', Modern philology, 85 (1987), 113-27, who challenges the allegorical and etymological interpretations of Unferth's name (typically construed as 'mar-peace'). Cf. Arthur Gilchrist Brodeur, The art of Beowulf (Berkeley, CA: University of California Press, 1959), pp. 151-5.

20 Rosier, 'Design for treachery', 7.

21 Norman E. Eliason, 'The Pyle and scop in Beowulf', Speculum, 38.2 (1963), 267-84.

22 Edward B. Irving, Jr, Rereading Beowulf (Philadelphia, PA: University of Pennsylvania Press, 1989), pp. 38, 47. For additional arguments about the centrality of Unferth's role in Hrothgar's court, see also Carol J. Clover, 'The Germanic context of the Unferp episode', Speculum, 55.3 (1980), 444-68; and Michael J. Enright, 'The warband context of the Unferth episode', Speculum, 73.2 (1998), 297-337.

23 For more on the function of secrecy in the poem, see Benjamin A. Saltzman, 'Secrecy and the hermeneutic potential in Beowulf', PMLA, 133.1 (2018), 36-55. 
24 The subsequent Sigemund digression likewise seems to parallel the 'sið Beowulfes' as well as his anticipated battle against the dragon at the end of the poem.

25 Megan Cavell, Weaving words and binding bodies: the poetics of human experience in Old English literature (Toronto: University of Toronto Press, 2016), pp. 238-3. On this formal pattern, see the seminal article by John Leyerle, 'The interlace structure of Beowulf', University of Toronto quarterly, 37.1 (1967), 1-17, at 4; on this passage and the poetic practice it imagines, see Norman E. Eliason, "The "improvised lay" in Beowulf', PQ, 31 (1952), 171-9.

26 This pattern is observed by Cavell, Weaving words and binding bodies, p. 239; but Renée R. Trilling, The aesthetics of nostalgia: historical representation in Old English verse (Toronto: University of Toronto Press, 2009), p. 12, reads it differently: 'The integrity of the long line is thus susceptible to disruption by semantics and poetics alike, and the simultaneous assertion and disruption of wholeness is the very fabric of the Anglo-Saxon poetic form.'

27 Thornbury, Becoming a poet, pp. 161-83, for example, has shown how Old English metrical and alliterative practices varied by poet, particularly poets (such as the 'renovator' of Christ and Satan) working in isolation.

28 Trilling, Aesthetics of nostalgia, pp. 11-12, elegantly reads the relationship between Beowulf, Sigemund, Heremod, and the dragon as a kind of Benjaminian 'constellation' where they 'share a space in a reflective moment that invokes them all'. Moreover, we see what Trilling calls 'the aesthetics of nostalgia' operating in Beowulf as it 'mediate[s] between a longing for communion with ancient heroes and the recognition that their antiquity sets them apart'.

29 Adrien Bonjour, The digressions in Beowulf (Oxford: Blackwell, 1950); for an overview, see Robert E. Bjork and John D. Niles (eds), A Beowulf handbook (Lincoln, NE: University of Nebraska Press, 1997). On the place of the Finn episode in the poem, see Scott Gwara, Heroic identity in the world of Beowulf (Leiden: Brill, 2008), pp. 135-80, who argues that it illustrates 'grave unease over Beowulf's appointment as Hrothgar's heir' (p. 151).

30 See Roberta Frank's chapter in this volume for another take on these lines, pp. 54-72.

31 Robert E. Bjork, 'Speech as gift in Beowulf', Speculum, 69.4 (1994), 993-1022, has taught us to see the function of speeches in the poem as a kind of gift giving, which is one of the central structures of community in the poem's hall culture. We might therefore see the force of speeches enhanced by their function as gifts in a gift-giving society, or inversely the exchanging of narratives could reinforce the social function of gift giving. There is a complex web of factors that influence the structure of community in the poem; I am merely arguing that narrative intimacy is one significant factor. 
32 My translation here differs from the editorial guidance of Fulk et al., Klaeber's Beowulf, pp. 180-1, which proposes 'Healgamen' as the subject of 'mænan scolde', and thus as an epithet for the scop. I have instead opted for the interpretation proposed by Eric Weiskott, 'Three Beowulf cruces: Healgamen, Fremu, Sigemunde', Notes and queries, 58.1 (2011), 3-7.

33 For a detailed study of the material and literary evidence of harps in this period, see Robert Boenig, 'The Anglo-Saxon harp', Speculum, 71.2 (1996), 290-320.

34 Benjamin, 'The storyteller', p. 87.

35 Ibid., pp. 87, 100.

36 It should be noted that, although Benjamin has in mind an abstracted image of medieval storytellers and the mists of oral tradition, he is almost certainly not thinking of Old English poetry or Beowulf.

37 Nancy, The inoperative community, pp. 50-1, considers the function of myth in community as 'the unique voice of the many'.

38 Benjamin, 'The storyteller', p. 102; see epigraph above for full quotation.

39 In multiple accounts, death is central to the formation of community. For example, for Nancy, The inoperative community, p. xvi, 'death is an experience that a collectivity cannot make its work or its property', so the finite singularity of the subject is what makes community ultimately impossible. On the other hand, Blanchot, The unavowable community, p. 9, takes that singularity as the very basis of community: 'to take upon myself another's death as the only death that concerns me, this is what puts me beside myself, this is the only separation that can open me, in its very impossibility, to the Openness of a community'. Esposito, Communitas, p. 13, sees the origin of community through a dark Hobbesian lens: 'What men have in common, what makes them more like each other than anything else, is their generalized capacity to be killed.' These different strains of thought share a kind of Derridean formulation, in which the irreducible experience of death - which cannot be given - is the very basis for the possibility of friendship; see Jacques Derrida, The gift of death and literature in secret, trans. David Wills (Chicago: University of Chicago Press, 2008), pp. 42-5; Jacques Derrida, The politics of friendship, trans. George Collins (New York: Verso, 1997), p. 14. On this formulation in early medieval England, see Benjamin A. Saltzman, 'Writing friendship, mourning the friend in late Anglo-Saxon Rules of Confraternity', $\mathcal{F M E M S , ~} 41.2$ (2011), 251-91.

40 Benjamin, 'The storyteller', pp. 93, 94.

41 Ibid., p. 102.

42 This inevitability is captured not only in Hrethel's lament for the demise of his son's hall, but also in elegies such as The Wanderer and The Ruin.

43 Patricia Dailey, 'Questions of dwelling in Anglo-Saxon poetry and medieval mysticism: inhabiting landscape, body, and mind', $N M L, 8$ (2006), 175-214. 
44 Maxims I, in George Philip Krapp and Elliott Van Kirk Dobbie (eds), The Exeter Book, ASPR 3 (New York: Columbia University Press, 1936; repr. 2004), pp. 156-63, at 162, lines 169-71.

45 Angus Cameron, Ashley Crandell Amos, and Antonette diPaolo Healey (eds), Dictionary of Old English: A to $H$ (Toronto: Dictionary of Old English Project, 2016), s.v. gliw.

46 Maxims $I$, lines 172-3.

47 E.g., Magennis, Images of community, p. 1.

48 Esposito, Communitas, pp. 56-7.

49 E.g., Daniel C. Remein, 'ISAS should probably change its name', paper presented at the International Congress on Medieval Studies (Kalamazoo, MI, 2017); Mary Dockray-Miller, 'Old English has a serious image problem', FSTOR Daily, 3 May 2017, https://daily.jstor.org/ old-english-serious-image-problem (accessed 4 June 2019).

50 Yet I am reminded that intimacy's optimism does not always play out in predictable ways or ways that are necessarily good for those estranged or subjugated by a dominant narrative of intimacy; see Berlant, 'Intimacy: a special issue', 281-2 and 288: 'Intimacy was supposed to be about optimism, remember? But it is also formed around threats to the image of the world it seeks to sustain.'

51 Serious conversations took place, for example, at conferences such as 'Seafaring: an early medieval conference on the islands of the North Atlantic' at the University of Denver, organized by Donna Beth Ellard and Dan Remein (3-5 November 2016), and the International Society of Anglo-Saxonists, Biennial Meeting, at the University of Hawai'i at Mānoa, Honolulu, HI (31 July-4 August 2017). 